\title{
Is ACE-27 a reliable method for predicting mortality of hip fractures treated with hemiarthroplasty in the elderly?
}

\author{
ACE-27, hemiartroplasti ile tedavi edilmiş yaşlı hastalardaki kalça \\ kırıklarında mortalitenin tahmininde güvenilir bir yöntem midir?
}

\author{
Mesut TAHTA ${ }^{1}$, Tugrul BULUT ${ }^{1}$, Tahir OZTURK ${ }^{1}$, Muhittin SENER ${ }^{1}$, Izge GUNAL ${ }^{2}$
}

\begin{abstract}
Several methods have been developed taking comorbid factors into consideration for prediction of the mortality risk in hip fractures in the elderly patients; but the perfect risk model for predicting mortality following hip fracture surgery does not exist. ACE-27 scoring method is basically a successful method for the prediction of the risk of mortality used in the oncology literature.The aim of this study was to examine the success of the ACE-27 scoring in the prediction of mortality by comparison with the accepted methods of $\mathrm{CCl}$ and ASA. An evaluation was made of the data of patients with the diagnosis of hip fracture in the elderly. Patients were examined in 2 groups. Group 1: 49 patients who died within 1 year postoperatively and Group 2: 65 patients who survived longer than 1 year. The patients of both groups were retrospectively scored using $C C l$ and $A C E-27$ scoring systems. The ASA scoring performed by an anesthetist was taken into consideration. The scoring systems were evaluated in terms of mortality and comparative effectiveness to each other. There were no significant differences between two groups with respect to age $(p=0.699)$, female: male ratio $(p=0.256)$, hospitalisation period ( $p=0.314)$, mean time from trauma to surgery $(p=0.375)$, mean duration of surgery $(p=0.421)$ A statistically significant relationship was found between the groups with respect to ACE$27(p<0.05), C C l$ and ASA ( $p<0.05)$ scorings. In the ROC analysis, the greatest area under the curve was obtained with the ACE-27 (AUC: 0.799). ACE-27 has the highest predictive power and is a valid and reliable method which could be used in the prediction of 1-year mortality in elderly patients with a hip fracture.
\end{abstract}

Keywords: Elderly, hip fracture mortality, risk prediction, scoring
Öz

Yaşlı hastalardaki kalça kırıklarında mortalitenin tahmin edilebilmesi amacıyla, komorbid faktörleri esas alan çeşitli skorlama yöntemleri geliștirilmiștir. Ancak kusursuz risk modeli ve tahmin gücüne halen ulaşılabilmiş değildir. ACE-27 skorlama yöntemi esas olarak onkoloji literatüründe kullanılan başarılı bir mortalite risk tespit yöntemidir. Mevcut çalışmanın amacı ACE-27 skorlama yönteminin, kabul görmüş ve yaygın kullanılan yöntemler olan $\mathrm{CCI}$ ve ASA ile karşılaştırarak yaşlı hastalardaki kalça kırıklarının mortalitesindeki tahmin gücünü ve başarısını ölçmektir. Çalışmamızda, kalça kırığı olan yaşlı hastaların bilgisi değerlendirmeye alındı. Hastalar 2 grup olarak düzenlendi: grup 1'de ameliyat sonrası 1 yıl içinde ölen 49 hasta varken; grup 2'de ameliyat sonrası 1 yıldan daha uzun yaşayan 65 hasta vardı. Her iki gruptaki hastalara retrospektif olarak dosya bilgileri üzerinden CCI ve ACE-27 skorlamaları yapıldı. ASA skorunda ise anestezistin yaptığı skor değeri esas alındı. Her üç skorlama sistemi mortaliteyi tahmin gücü açısından karşılaştırıldı. Her iki grup arasında yas $(p=0.699)$, kadın-erkek oranı $(p=0.256)$, hastanede kalış süresi $(p=0.314)$, travmadan ameliyata kadar geçen süre $(p=0.375)$, ortalama ameliyat süresi $(p=0.421)$ açsindan fark yoktu. Gruplar arasında ACE-27 $(p<0.05), C C l$ ve ASA $(p<0.05)$ değerleri açısından anlamlı fark mevcuttu. ROC analizinde eğri altında kalan alan en fazla ACE-27 ile elde edildi (AUC: 0.799). Yaşlı hastalardaki kalça kırıklarının 1 yıllık mortalitesinin tahmininde ACE-27, CCl ve ASA'ya göre daha etkin, güvenilir bir skorlama yöntemidir ve ortopedi ve travmatoloji pratiği içinde güvenle kullanılabilir.

Anahtar kelimeler: Yaşlı, kalça kırığı, mortalite, risk tahmini, skorlama

\section{INTRODUCTION}

Hip fractures in elderly patients have the highest mortality rates (20\%-25\%) encountered in orthopaedic practice within the first year of the incident ${ }^{1-3}$. Management is one of the most important problems because of problematic comorbidities ${ }^{4,5}$. In this context, determination of this risk with effective, accurate and reproducible criteria is important for therapeutic decision making, patients and family counseling 6,7 .

It has been reported that postoperative mortality rates can be estimated by quantifying the patient's

Received: 01.11.2016

Accepted: 15.11 .2016

${ }^{1}$ Katip Celebi University, Izmir Ataturk Training and Research Hospital, Department of Orthopaedics and Traumatology

${ }^{2}$ Dokuz Eylul University, Faculty of Medicine, Department of Orthopaedics and Traumatology

Yazışma adresi: Mesut Tahta, Katip Celebi University, Izmir Ataturk Training and Research Hospital, Department of Orthopaedics and Traumatology, Karabaglar, 35000, Izmir

e-mail: mesuttahta@gmail.com 
physiological status ${ }^{8}$. Therefore, several scoring methods have been created taking comorbid factors into consideration, which would be of benefit in the prediction of mortality. The Charlson Comorbidity Index (CCI) and the American Society of Anaesthesiologists score (ASA) have been widely used in the prediction of mortality ${ }^{1,7,9-11}$. Although many scoring systems have been described in the literature, the perfect risk model for predicting mortality following hip fracture surgery does not exist, and research on the subject is ongoing ${ }^{12}$. When literature is examined, it can be seen that the Adult Comorbidity Evaluation-27 (ACE27) has been used successfully in the prediction of mortality in fields such as haematology, urology and clinical oncology, although to the best of our knowledge it has not been evaluated yet in the field of orthopaedics and traumatology ${ }^{13-16}$.

The aim of this study was to examine for the first time in orthopaedics and traumatology literature, the success of the ACE-27 scoring method in the prediction of mortality and to evaluate the potential need for it by comparison with the accepted methods of $\mathrm{CCl}$ and ASA.

\section{MATERIAL and METHODS}

A retrospective evaluation was made of the data of patients who were admitted, treated and followed up with the diagnosis of hip fracture between January 2012 and April 2013. Then, current status of survival or date of death was determined from the files of population registration system.

Patients aged $\geq 65$ years with an isolated acute hip fracture including femoral neck or intertrochanteric femoral fracture who were able to walk independently before the operation, and operated on with the application of uncemented hemiarthroplasty by a senior orthopaedic surgeon under spinal anaesthesia then followed up for at least 1 year were included in the study. Patients in the terminal stages of any illness with concomitant head or thorax injury that required intervention were excluded from the study. In addition, 8 patients with missing data, those with whom any contact could not be established or scoring system could not be applied because they had lost to follow-up for various reasons were also excluded from the study. Thus, patients who met the criteria were examined in 2 groups as Group 1 of 49 patients who died within 1 year postoperatively and Group 2 of 65 patients who survived more than 1 year postoperatively.

The patients of both groups were retrospectively scored on the $\mathrm{CCl}$ and ACE-27 by an orthopaedic surgeon. The basis of the scoring was taken as the ASA scoring in the patient record completed by the anaesthetist. Data obtained from the patient and hospital records were used in the evaluation. The scoring systems were evaluated with respect to mortality and their comparative effectiveness.

Statistical analysis of the data was made with IBM SPSS StatisticsVersion 22 software. In the comparison of categorical variables between the groups, the Pearson chi-square test, Fisher's Exact test and Chi-square trend were used. When continuous varriables did not show normal distribution (Kolmogorov-Smirnov and Shapiro-Wilk $p<0.05$ ), the Mann Whitney U-test was used in the statistical analysis of the comparisons between groups. The predictive power of the ASA, $\mathrm{CCl}$ and $\mathrm{ACE}-27$ variables for mortality was evaluated with ROC analysis. A value of $p<0.05$ was accepted as statistically significant.

\section{RESULTS}

The median age of the patients was 81.9 years (range, 65-100 years) in Group 1 and 81.6 years (range, 65-97 years) in Group 2 and there was no statistically significant difference between the groups $(p=0.699)$. The female: male ratio was 32:17 in Group 1 and 43:22 in Group 2 and the difference between the groups was not significant $(p=0.256)$. There was no significant differences in terms of total hospitalisation time $(p=0.314)$, operative time $(p=0.375)$ and mean duration of surgery $(p=0.421)$ between two groups.

Distribution of the patients according to the scoring systems is shown in Table 1. 
Table 1. Distribution of the patients and comparison of the groups according to the scoring systems.

\begin{tabular}{|c|c|c|c|c|c|c|}
\hline & & \multicolumn{2}{|c|}{ Group 1} & \multicolumn{2}{|c|}{ Group 2} & \multirow[b]{2}{*}{$p$ value } \\
\hline & & $\mathrm{n}$ & $\%$ & $\mathrm{n}$ & $\%$ & \\
\hline \multirow[t]{5}{*}{ ASA } & 1 & - & - & - & - & \multirow{5}{*}{$0.009 *$} \\
\hline & 2 & 3 & 6.1 & 14 & 21.6 & \\
\hline & 3 & 25 & 51.0 & 35 & 53.8 & \\
\hline & 4 & 21 & 42.9 & 16 & 24.6 & \\
\hline & Mean $\pm S D$ & & \pm 0.6 & & \pm 0.68 & \\
\hline \multirow[t]{4}{*}{$\mathrm{CCl}$} & $3-4$ & 1 & 2.0 & 5 & 7.6 & \\
\hline & $5-6$ & 16 & 32.6 & 38 & 58.4 & \\
\hline & $7-8$ & 17 & 34.6 & 16 & 24.6 & \multirow[b]{2}{*}{$0.000 *$} \\
\hline & Mean $\pm S D$ & & \pm 2.05 & & \pm 1.54 & \\
\hline \multirow[t]{5}{*}{ ACE-27 } & G0 & - & - & - & - & \multirow{5}{*}{$0.001 * *$} \\
\hline & G1 & 8 & 16.3 & 46 & 70.8 & \\
\hline & $\mathrm{G} 2$ & 15 & 30.6 & 11 & 16.9 & \\
\hline & G3 & 26 & 53.1 & 8 & 12.3 & \\
\hline & G9 & - & - & - & - & \\
\hline
\end{tabular}

SD: Standard deviation, *Mann Whitney $U$ analysis, ** Chi-square trend analysis

Table 2. The results of the ROC analysis for ASA, CCI and ACE-27.

\begin{tabular}{lll}
\hline & AUC* & p \\
\hline ASA & 0.630 & 0.006 \\
CCI & 0.716 & $<0.001$ \\
ACE-27 & 0.799 & $<0.001$ \\
\hline
\end{tabular}

*Area under curve

A statistically significant relationship was found between the groups with respect to ACE-27 scoring, mortality rate increased in paralel with the scoring grade $(p<0.05)$ (Table 1$)$.

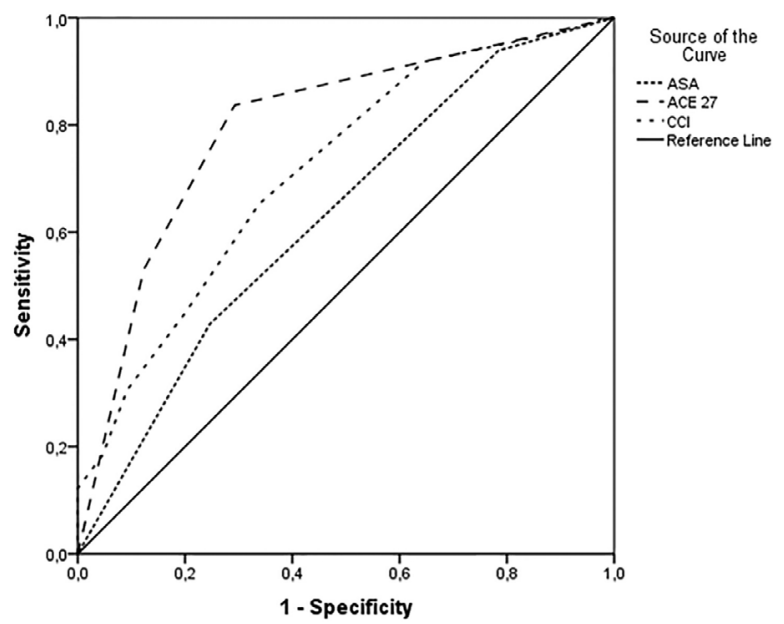

Figure 1. ROC curve drawn for the ASA, $\mathrm{CCl}$ and $\mathrm{ACE}$ variables in mortality prediction.
The $\mathrm{CCl}$ and ASA values of the dead patients were found to be statistically significantly higher than those of the surviving patients $(p<0.05)$ (Table 1$)$.

The predictive power of the three variables for mortality was determined to be statistically significant $(p<0.05)$ (Table 2 ) in ROC analysis and the greatest area under the curve was obseved to be in the ACE27 (AUC: 0.799) (Figure 1).

\section{DISCUSSION}

Determination of the mortality risk of hip fractures in elderly patients should be evaluated as an important prerequisite but when orthopaedics and traumatology literature is examined, it can be seen that there is limited number of studies on this issue, and an adequate and also effective method has not been developed yet t, $, 12,17-19$. Within this context, the current study is the first in orthopaedics and traumatology literature to show that the ACE-27 scoring system could be of use in the determination of mortality risk at 1-year following hip fractures in elderly patients who have a relatively high mortality rate.

Although many scoring systems have been desig- 
ned for hip fractures, $\mathrm{CCl}$ seems to be the frequently used in the prediction of mortality following fracture surgery ${ }^{7,9,20,21}$. In a study by Kirkland et al., ${ }^{22}$ on hip fractures in elderly patients, a strong relationship was found between a $\mathrm{CCl}$ score of $>6$ and 30-day mortality rates but no comment was made about sensitivity or specificity of $\mathrm{CCl}$ scoring system. In the current study, the area under curve (AUC) in the ROC analysis for $\mathrm{CCl}$ was determined, $\mathrm{CCl}$ scores of $\geq 0.716$ was associated with higher mortality rates. In mortality prediction models it has been reported that an AUC between 0.70 and 0.79 is considered to represent an acceptable discrimination, and an AUC between 0.80 and 0.89 is considered excellent ${ }^{23}$. In a recent study by Karres et al on hip fractures in elderly patients, the AUC for $\mathrm{CCl}$ was determined as 0.71 , which showed high consistency with the findings of the current study ${ }^{12}$. Furthermore when the inclusion and exclusion criteria of Kirkland et al..$^{22}$ and Karres et al. ${ }^{12}$ were examined, it can be revealed that, all elderly patients probably with hip fractures including those with terminal stage disease, those with another injury which could affect mortality in addition to the hip fracture and those who could not walk preoperatively were all included in their study. It can also be seen that the type of surgery applied was different in that during hemiarthroplasty, cannulated screws, dynamic hip screws or intramedullary nails had been used. Even though this is a debatable subject in literature, surveys could be different with respect to mortality according to the type of surgery applied for hip fractures. It seems that they investigated 'all cause mortality' of hip fractures. But we think that considering different surgical techniques with different surveys when evaluating prediction power of a method, may significantly affect the result and study groups should be as specific as possible.

ASA scoring is another method accepted in the literature for the prediction of mortality ${ }^{25,26}$. As in the $\mathrm{CCl}$, the ASA is not a method specifically designed for hip fractures. In a meta-analysis, studies related to 1-year follow-up of hip fractures were examined and it was found that both higher ASA grade and higher $\mathrm{CCl}$ score were statistically significant indicators of mortality at 12 months following hip fracture ${ }^{27}$. In the current study, AUC for ASA in RC analysis was 0.63 and patients with higher ASA scores had a higher risk of mortality.

The most successful prediction seems to be achieved with the ACE-27 scoring system. There are several reasons for this, including that the scale presents the possibility of an extremely comprehensive evaluation by examining 26 comorbid factors which are staged in 5 grades). The ACE-27 scoring system was primarily designed for use in newly-diagnosed cases of cancer ${ }^{28}$. Piccirillo et al. ${ }^{29}$ modified the KaplanFeinstein Index to be used for similar purposes and this is now in the form known as the ACE-27. In addition to its comprehensiveness, the categorisations are very detailed and absolute limits have been defined. However, despite all of these favourable features, it is somewhat time-consuming to apply and it takes about 10 minutes for one patient. But when we consider success of predicting mortality it can be used as a bedside clinical tool. According to data in the related oncology literature, Hines et al retrospectively evaluated the success of 3 different scoring systems, including ACE-27, CCl, ASA applied for the prediction of mortality risk following surgery in patients with colon cancer and concluded that for patients with severe comorbidity, all three indices were strikingly similar and statistically significant in predicting shorter survival after surgery for colon cancer ${ }^{15}$. Similarly, in urology literature, Zhu et al..$^{30}$ examined the effectiveness of ACE-27 in cases with bladder cancer and reported that the scoring was a valid and a reliable tool. Using these data in literature, when ACE-27 was used in orthopaedics and traumatology literature in the prediction of mortality after hip fractures in elderly patients who have relatively high mortality, ACE-27 with an AUC of 0.799 was seen to be more successful than $\mathrm{CCl}$ and ASA.

Major limitation of the current study is the limited number of patients and its retrospective design. We aimed to discard all possibilities which could affect the mortality and the survey. Prediction of hip fracture mortality by creating two very specific and 
homogenous patient groups was attempted. Even though there were two major fracture types in the study groups only uncemented hemiarthroplasty was used,and we evaluated all methods on the basis of this procedure. Unfortunately, as a result of this study perspective, the number of patients included in the study groups became lesser. Surely, prospective studies with larger series are mandatory for more strict conclusions.

In conclusion, $\mathrm{CCl}$ and $\mathrm{ACE}-27$ scoring methods can be used to predict mortality in elderly patient with a hip fracture. Of ASA, CCI and ACE-27, ACE-27 has the highest predictive power and is a valid and reliable method which could be used in the prediction of 1-year mortality in elderly patients with a hip fracture.

\section{REFERENCES}

1. Hu F, Jiang C, Shen J et al. Preoperative predictors for mortality following hip fracture surgery: a systematic review and meta-analysis. Injury 2012;43:676-685. https://doi.org/10.1016/j.injury.2011.05.017

2. Center JR, Nguyen TV, Schneider D et al. Mortality after all major types of osteoporotic fracture in men and women: an observational study. Lancet 1999;353:878-882. https://doi.org/10.1016/S0140-6736(98)09075-8

3. Osnes EK, Lofthus CM, Meyer HE et al. Consequences of hip fracture on activities of daily life and residential needs. Osteoporos Int 2004;15:567-574.

https://doi.org/10.1007/s00198-003-1583-0

4. Maxwell MJ, Moran CG, Moppett IK. Development and validation of a preoperative scoring system to predict 30 day mortality in patients undergoing hip fracture surgery. $\mathrm{Br} J$ Anaesth 2008;101:511-517. https://doi.org/10.1093/bja/aen236

5. Talsnes O, Vinje T, Gjertsen JE et al. Perioperative mortality in hip fracture patients treated with cemented and uncemented hemiprosthesis: a register study of 11,210 patients. Int Orthop 2013;37:1135-1140. https://doi.org/10.1007/s00264-013-1851-3

6. van Doorn C, Borgardus ST, Williams CS et al. Risk adjustment for older hospitalized persons: a comparison of two methods of data collection for the Charlson index. J Clin Epidemiol 2001;54:694-701. https://doi.org/10.1016/S0895-4356(00)00367-X

7. Voskuijl T, Hageman M, Ring D. Higher Charlson Comorbidity Index Scores are associated with readmission after orthopaedic surgery. Clin Orthop Relat Res 2014;472:1638-1644. https://doi.org/10.1007/s11999-013-3394-8

8. Hirose J, Mizuta $\mathrm{H}$, Ide J et al. E-PASS for predicting postoperative risk with hip fracture: a multicenter study. Clin Orthop Relat Res 2008;466:2833-2841.

https://doi.org/10.1007/s11999-008-0377-2
9. Neuhaus V, King J, Hageman MG et al. Charlson comorbidity indices and in-hospital deaths in patients with hip fractures. Clin Orthop Relat Res 2013;471:1712-1719. https://doi.org/10.1007/s11999-012-2705-9

10. Liu Y, Peng M, Lin L et al. Relationship between American Society of Anesthesiologists (ASA) grade and 1-year mortality in nonagenarians undergoing hip fracture surgery. Osteoporos Int 2015;26:1029-1033. https://doi.org/10.1007/s00198-014-2931-y

11. Mayr R, May M, Martini T, et al. Predictive capacity of four comorbidity indices estimating perioperative mortality after radical cystectomy for urothelial carcinoma of the bladder. BJU Int 2012;110:222-227. https://doi.org/10.1111/j.1464-410X.2012.10938.x

12. Karres J, Heesakkers NA, Ultee JM et al. Predicting 30 day mortality following hip fracture surgery: evaluation of six risk prediction models. Injury 2015;46:371-377. https://doi.org/10.1016/j.injury.2014.11.004

13. Bellizzi KM, Mustian KM, Palesh OG et al. Cancer survivorship and aging: moving the science forward. Cancer 2008;113:3530-3539. https://doi.org/10.1002/cncr.23942

14. Breccia M, Latagliata R, Stagno F et al. Charlson comorbidity index and adult comorbidity evaluation-27 scores might predict treatment compliance and development of pleural effusions in elderly patients with chronic myeloid leukemia treated with second-linedasatinib. Haematologica 2011;96:1457-1461. https://doi.org/10.3324/haematol.2011.041251

15. Hines RB, Chatla C, Bumpers HL et al. Predictive capacity of three comorbidity indices in estimating mortality after surgery for colon cancer. J Clin Oncol 2009;27:4339-4345. https://doi.org/10.1200/JCO.2009.22.4758

16. Naqvi K, Garcia-Manero G, Sardesai S et al. Association of comorbidities with overall survival in myelodysplastic syndrome: development of a prognostic model. J Clin Oncol 2011;29:2240-2246. https://doi.org/10.1200/JCO.2010.31.3353

17. Toson B, Harvey LA, Close JC. The ICD-10 Charlson Comorbidity Index predicted mortality but not resource utilization following hip fracture. J Clin Epidemiol 2015;68:44-51. https://doi.org/10.1016/j.jclinepi.2014.09.017

18. van Zeeland ML, Genovesi IP, Mulder JW et al. POSSUM predicts hospital mortality and long-term survival in patients with hip fractures. J Trauma 2011;70:67-72. https://doi.org/10.1097/TA.0b013e3181edbf7a

19. Wiles MD, Moran CG, Sahota O et al. Nottingham Hip Fracture Score as a predictor of one year mortality in patients undergoing surgical repair of fractured neck of femur. $\mathrm{Br} \mathrm{J}$ Anaesth 2011;106:501-504. https://doi.org/10.1093/bja/aeq405

20. Lix LM, Quail J, Teare G et al. Performance of comorbidity measures for predicting outcomes in population-based osteoporosis cohorts. Osteoporos Int 2011;22:2633-2643. https://doi.org/10.1007/s00198-010-1516-7

21. Charlson ME, Pompei P, Ales KL et al. A new method of classifying prognostic comorbidity in longitudinal studies: development and validation. J Chronic Dis 1987;40:373-383. https://doi.org/10.1016/0021-9681(87)90171-8

22. Kirkland LL, Kashiwagi DT, Burton MC et al. The Charlson Comorbidity Index Score as a predictor of 30-day mortality after hip fracture surgery. Am J Med Qual 2011;26:461-467. https://doi.org/10.1177/1062860611402188

23. Hosmer DW, Lemeshow S. Applied logistic regression. New 
York, USA: Wiley; 2004: 48-50.

24. Leonardsson O, Sernbo I, Carlsson A et al. Long-term follow-up of replacement compared with internal fixation for displaced femoral neck fractures: results at ten years in a randomised study of 450 patients. J Bone Joint Surg Br 2010;92:406-412. https://doi.org/10.1302/0301-620X.92B3.23036

25. Owens WD, Felts JA, Spitznagel EL Jr. ASA physical status classifications: a study of consistency of ratings. Anesthesiology 1978;49:239-243. https://doi.org/10.1097/00000542-197810000-00003

26. Pereira SR, Puts MT, Portela MC et al. The impact of prefracture and hip fracture characteristics on mortality in older persons in Brazil. Clin Orthop Relat Res 2010;468:1869-1883. https://doi.org/10.1007/s11999-009-1147-5

27. Smith T, Pelpola K, Ball M et al. Pre-operative indicators for mortality following hip fracture surgery: a systematic review and meta-analysis. Age Ageing 2014;43:464-471. https://doi.org/10.1093/ageing/afu065

28. Piccirillo JF, Feinstein AR. Clinical symptoms and comorbidity: significance for the prognostic classification of cancer. Cancer 1996;77:834-842.

https://doi.org/10.1002/(SICI)1097-0142(19960301)77:5 $<834:$ :AID-CNCR5>3.0.CO;2-E

29. Kaplan MH, Feinstein AR. The importance of classifying initial co-morbidity in evaluating the outcome of diabetes mellitus. J Chron Dis 1974;27:387-404. https://doi.org/10.1016/0021-9681(74)90017-4

30. Zhu X, Zhong ZH, Zhang XZ et al. Comorbidity relationship to outcome of radical cystectomy in Chinese: a single institution study with the ACE-27comorbidity index. Asian Pac J Cancer Prev 2012;13:827-831.

https://doi.org/10.7314/APJCP.2012.13.3.827 